\title{
ENTRADA NO CAMPO, ACEITAÇÃO E NATUREZA DA PARTICIPAÇÃO NOS ESTUDOS ETNOGRÁFICOS COM CRIANÇAS PEQUENAS*
}

\author{
William A. CORSARo ${ }^{* *}$
}

\begin{abstract}
RESUMO: Fazer pesquisa etnográfica com crianças pequenas envolve um certo número de desafios uma vez que os adultos são percebidos como poderosos e controladores de suas vidas. Este artigo relata minhas pesquisas etnográficas comparativas com crianças de pré-escolas nos Estados Unidos e na Itália. Enfoco mais particularmente a entrada no campo, o estabelecimento do status de participante e a coleta de notas de campo e de dados audiovisuais. Faço uma breve revisão dos procedimentos de entrada no campo que usei nos locais de pesquisa de campo nos Estados Unidos e na Itália. Discuto como, com o tempo, passei a fazer "pesquisa com, e não mais sobre, crianças", ou seja, como meus métodos de coleta de dados acabaram se tornando gradualmente mais abertos à contribuição direta das crianças. Finalmente, usando a pesquisa de Modena, na Itália, discuto uma etnografia longitudinal ao longo de períodos-chave de transição na vida das crianças. Essa etnografia implicou que permanecesse com e continuasse observando e entrevistando as crianças quando entraram na primeira série e durante seus cinco anos de escola primária.
\end{abstract}

Palavras-chave: Etnografia. Culturas de pares das crianças. Educação pré-escolar. Estados Unidos e Itália.

\footnotetext{
* Este artigo é uma versão ligeiramente modificada do capítulo 1 de Wére friends, right? Inside kid culture (Somos amigos, certo? No interior da cultura das crianças). Washington: Joseph Henry Press, 2003.

Tradução de Alain François, com revisão técnica de Fernanda Müller.

** Departamento de Sociologia da Universidade de Indiana (EUA). E-mail: corsaro@indiana.edu
} 
Entrada no campo, aceitação e natureza da participação nos estudos...

FIELD ENTRY, ACCEPTANCE AND NATURE OF PARTICIPATION IN ETHNOGRAPHIC STUDIES WITH YOUNG CHILDREN

ABSTRACT: Doing ethnographic research with young children involves a number of challenges as adults are perceived as powerful and controlling of children's lives. In this paper I review my comparative ethnographic research of preschool children in the United States and Italy. The focus is on field entry, establishing participant status, and the collection of field notes and audiovisual data. I briefly review field entry procedures I employed in field sites in the United States and Italy. I discuss how my data collection methods over time became gradually more open to children's direct input which is what I mean by "research with as opposed to on children". Finally, using the research from Modena, Italy I discuss a longitudinal ethnography across key transition periods in children's lives. This ethnography involved my staying with and continuing to observe and interview the children as the entered first grade and throughout their five years of elementary school.

Key words: Ethnography. Children's peer cultures. Preschool education, United States and Italy.

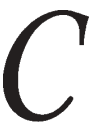

omo Tom Rizzo, Jack Bates e eu argumentamos que a entrada no campo é crucial na etnografia, uma vez que um de seus objetivos centrais como método interpretativo é estabelecer o status de membro e uma perspectiva ou ponto de vista de dentro (Rizzo et al., 1992). A aceitação no mundo das crianças é particularmente desafiadora por causa das diferenças óbvias entre adultos e crianças em termos de maturidade comunicativa e cognitiva, poder (tanto real como percebido) e tamanho físico (Corsaro, 1985).

Ao passo que alguns etnógrafos de crianças (Mandell, 1988) afirmam que uma aceitação completa (dos pesquisadores pelas crianças) é possível e uma participação plena (dos pesquisadores nos universos das crianças) é desejável, outros sustentam que certas diferenças entre adultos e crianças (especialmente o tamanho físico) podem não ser plenamente superadas e, portanto, aconselham alguma forma de participação limitada ou periférica (Corsaro, 1985; Fine \& Sandstorm, 1988). Outros ainda alegam que estudar os próprios filhos, ser pai ou mãe pesquisador (Adler \& Adler, 1998), permite evitar muitos problemas e superar a necessidade de formar o que chamam de uma "relação criada pelo pesquisador e, logo, um tanto artificial”. Contudo, para mim, a 
estratégia dos pais pesquisadores acarreta muitos conflitos de papel que excedem em muito sua utilidade prática. Seja como for, as decisões quanto ao grau e à natureza da participação variarão em função do local particular de pesquisa etnográfica de campo.

Independentemente do grau de participação adotado, contudo, uma documentação de entrada, aceitação e participação é imperativa nos estudos etnográficos, por vários motivos. Muito obviamente essa documentação permite estimar possíveis efeitos disruptivos do processo de pesquisa sobre o fluxo normal de rotinas e práticas culturais. A preocupação, neste caso, não é tanto com o grau de participação, mas com os efeitos das práticas rotineiras de coleta de dados (como entrevistas informais, anotaçōes, gravações audiovisuais e coleta de artefatos). Além do mais, e de modo mais sutil, uma vez que entrada, aceitação e participação são processos com histórias de desenvolvimentos, sua documentação fornece a visualização dos processos produtivos e reprodutivos nas culturas locais.

Acredito que toda etnografia se beneficiaria (tanto metodológica quanto teoricamente) de uma documentação cuidadosa do processo de entrada em campo. Mais uma vez, quero salientar que essa documentação nunca pode ser completamente incluída em publicações porque, em sentido prático, constituiria, em si e por si, um longo capítulo, um artigo extenso de periódico ou até mesmo um livro. Por exemplo, nos meus primeiros trabalhos, muitas vezes passei por cima da minha aceitação por parte dos adultos (principalmente professores) por fazer pouco caso dela. Entretanto, em trabalhos posteriores, na Itália, como discuti num artigo com minha colega Luisa Molinari (Corsaro \& Molinari, 2000), prestamos muito mais atenção na nossa aceitação pelos professores e trabalhamos como uma equipe para realizar a entrada em campo.

Neste artigo relato como realizei minha entrada em campo e consegui ser aceito na escola local e nas culturas de pares de várias das préescolas que estudei nestes últimos 28 anos. De modo geral, vejo que, durante este tempo, meu trabalho de campo foi passando de uma pesquisa sobre para uma pesquisa com crianças (ver Christensen \& James, 2000).

\section{Tornar-se um etnógrafo das culturas de crianças}

Entro no pátio externo de recreio da pré-escola e me dirijo até duas meninas de 4 anos, Betty e Jenny, que estão sentadas no monte 
Entrada no campo, aceitação e natureza da participação nos estudos...

de areia. Assim que me aproximo delas, a Betty diz: "Você não pode brincar com a gente!"

- "Por que não?", pergunto.

- "Porque é grande demais", responde a Betty. meninas.

- "Vou sentar", digo, enquanto me deixo cair na areia perto das

- "Ainda tá grande demais", diz a Jenny.

- "É, cê é o Grande Bill!", grita a Betty.

- "Posso olhar?", pergunto.

- "Tá”, diz a Jenny, "mas não toca em nada!"

- "É", diz a Betty, "só olha, tá?"

- "Tá".

- “Tá, Grande Bill?”, pergunta a Jenny.

- “Tá." (Mais tarde "Grande Bill” conseguiu brincar.)

A etnografia é o método que os antropólogos mais empregam para estudar as culturas exóticas. Ela exige que os pesquisadores entrem e sejam aceitos na vida daqueles que estudam e dela participem. Neste sentido, por assim dizer, a etnografia envolve "tornar-se nativo". Estou convicto de que as crianças têm suas próprias culturas e sempre quis participar delas e documentá-las. Para tanto, precisava entrar na vida cotidiana das crianças - ser uma delas tanto quanto podia.

Mas o que há de fazer um homem crescido para ser aceito nos universos das crianças? Quando iniciei minha pesquisa não existiam modelos definidos para se seguir. Então, quando de minha entrada nas primeiras das muitas pré-escolas que estudei nos Estados Unidos e na Itália, decidi que a melhor maneira para tornar-me parte dos universos das crianças era "não agir como um adulto típico". Este artigo descreve como consegui fazer isso em vários dos diferentes ambientes de educação da infância dos quais me tornei parte e onde convivi com crianças, seus professores e pais. Mas comecemos pelo começo, muitos anos atrás, em Berkeley, Califórnia.

\section{Berkeley, Califórnia (1974-1975)}

Ao me preparar para minha pesquisa em Berkeley, segui a opinião de uma professora, Margaret, e passei algumas semanas observando a interação na escola de uma área de observação escondida. Ela ponderou 
que nas primeiras semanas de escola as crianças ainda estão se adaptando aos novos ambientes e que pais e professores também andam ligeiramente tensos com o início do novo ano. Portanto, sugeriu que eu observasse de uma parte especial, instalada ao longo das áreas interna e externa da escola, de onde poderia ver sem ser visto. Essa área de observação era usada por pais e por psicólogos do desenvolvimento de uma universidade vizinha, em suas pesquisas observacionais. Nos meus primeiros dias de observação eu fiquei aturdido pelo número, leque e pela complexidade de acontecimentos interativos que ocorriam diante de meus olhos. No primeiro dia, como não tinha uma idéia clara do que escrever nas minhas notas de campo, apenas olhei e tentei dar um sentido geral às coisas. Nos dias seguintes comecei a focalizar o que ocorria, quando e onde na escola, e descobri uma rotina geral. Também comecei a fazer um inventário das várias atividades de que as crianças participavam, tanto as dirigidas pelos professores como as que elas próprias criavam. Também aprendi aos poucos todos os nomes das crianças e, até um certo ponto, conheci suas várias personalidades.

$\mathrm{Na}$ terceira semana comecei a considerar como eu ia entrar e ser aceito naquele grupo de crianças que estavam se tornando mais familiares para mim. Como queria tentar me envolver diretamente nas interaçóes de pares das crianças, não queria ser visto como um adulto típico. Meu primeiro passo para descobrir o que fazer foi observar de perto como os adultos interagiam com as crianças. Eis o que vi: os adultos eram principalmente ativos e controladores em sua interação com as crianças. Por exemplo, os pais e outros adultos que visitavam a escola costumavam se aproximar das crianças, iniciavam uma interação e faziam muitas perguntas. Vejamos um exemplo:

Um dia, uma mãe que visitava a escola se aproximou da mesa onde duas meninas estavam desenhando. Ficou um tempo debruçando-se e olhando para baixo, para as meninas.

- "O que estão desenhando?", perguntou.

- "Uma árvore", respondeu uma das meninas.

Houve um silêncio durante o qual as meninas continuaram seus trabalhos.

- "De que cor é a árvore?", perguntou a mãe.

- "Verde", disse uma delas sem olhar para cima e continuando a desenhar. 
Entrada no campo, aceitação e natureza da participação nos estudos...

- “O que mais é verde?”, perguntou a mãe.

Outro silêncio e então a outra menina disse: - "A grama".

A mãe então se endireitou, olhou ao redor da sala e foi para outro lugar.

Os adultos querem iniciar conversas com crianças, mas não se sentem à vontade com as respostas mínimas das crianças e sua tolerância para o que (para os adultos) parecem ser longos silêncios. Muitas vezes, como no exemplo anterior, os adultos começam fazendo perguntas-teste (coisas para as quais já conhecem as respostas, como a cor de uma árvore) para ver o que as crianças estão pensando a respeito do que estão fazendo ou simplesmente para transformar a troca em experiência de aprendizagem.

Por sua vez, os professores também faziam muitas perguntas, mas eram mais sofisticados no desenvolvimento do potencial de aprendizagem de suas conversas e interações com crianças. Eles também dirigiam e monitoravam as brincadeiras das crianças, ajudavam-nas em casos de problema e diziam-lhes o que podiam ou não podiam fazer. Finalmente, percebi que os adultos (professores ou visitantes) restringiam seu contato com as crianças a áreas específicas da pré-escola. Os adultos raramente entravam nas casas de boneca, nas caixas de areia, nas barras de escalada ou no trepa-trepa.

Vendo como os adultos eram ativos e controladores em sua interação com as crianças na pré-escola, decidi adotar uma estratégia de entrada "reativa". Na minha primeira semana na escola, fiquei continuadamente em áreas dominadas pelas crianças e esperei que elas reagissem à minha presença. Nos primeiros dias, os resultados não foram encorajadores. Além de alguns sorrisos e olhares perplexos, as crianças me ignoravam. Das centenas de horas em que observei pré-escolas, essas foram as mais difíceis para mim. Queria dizer alguma coisa ("qualquer coisa”) às crianças, mas insisti na minha estratégia e permaneci calado.

$\mathrm{Na}$ minha quarta tarde na pré-escola, fiquei na caixa de areia bem atrás de um grupo de cinco crianças (quatro meninos e uma menina) que estavam cavando a areia com pás, brincando de "trabalho de construção" com dois chefes e três trabalhadores (quatro meninos e uma menina). A construção envolvia dois dos meninos que cavavam uma trincheira na areia e um que a enchia de água enquanto um quarto (o "barrageiro") ficava enfiando e tirando a sua pá em vários pontos da trincheira para criar a barragem. Ele fazia isso sob as ordens da chefa. Assisti a essa brin- 
cadeira complexa por mais de 40 minutos. Então, primeiro dois dos meninos, e logo a seguir os outros dois, enfiaram suas pás na areia, e correram para dentro da escola com a chefa atrás deles. Suspeitei que não planejavam voltar e que o projeto de construção acabara de ser abandonado.

Eu não estava me sentindo à vontade e pensei em qual seria meu próximo passo quando percebi a Sue. Ela estava sozinha, perto da caixa de areia, a uns seis metros de mim, e estava claramente olhando para mim. Sorri e ela sorriu de volta, mas então, para meu espanto, ela correu até a caixa de areia e ficou olhando um grupo de três outras meninas. Então, houve um tumulto perto das barras de escalada. Olhei e vi que o Peter havia roubado (pelo menos era o que o Daniel alegava) o caminhão do Daniel. Uma professora logo chegou para acalmar a briga, e, quando olhei de novo para a caixa de areia, Sue já não estava mais lá.

Estava me levantando para ir para dentro da escola, quando ouvi alguém dizer: "Que que cê tá fazendo?". Sue tinha se aproximado por trás e, agora, estava perto de mim, na caixa de areia.

- "Só tô olhando", disse.

- "Para quê?", ela perguntou.

- "Porque gosto". Então, ela perguntou meu nome. Eu disse (e isso foi importante):

- "Sou o Bill e você é a Sue". Ela recuou dois passos e perguntou:

- "Como você sabe meu nome?".

Fiz então uma coisa que adultos não costumam fazer quando falam com crianças pequenas, especialmente quando pensam que elas não vão entender a resposta: Disse a verdade sem tentar simplificar.

- "Ouvi Laura e algumas outras crianças te chamar de Sue".

- "Mas como você sabe o meu nome?", perguntou a Sue de novo.

Batendo na mesma tecla, repeti que havia ouvido que outras crianças a chamavam de Sue. Ela me olhou atônita, virou bruscamente e correu para dentro da escola. Que maravilha! Após vários dias tentando me tornar uma das crianças, e quando, finalmente, uma delas fala comigo eu a apavoro! Mas então a Sue voltou da escola e veio correndo até mim, com o Jonathan. Quando chegaram, o Jonathan perguntou:

- "Como me chamo?".

- "Jonathan", respondi. 
Entrada no campo, aceitação e natureza da participação nos estudos...

- "Como você sabe meu nome?".

- "Ouvi o Peter [um garoto com quem costumava brincar] e algumas outras crianças te chamar de Jonathan", disse.

- "Viu, não disse que ele sabe mágica?", disse a Sue.

- "Não, não, peraî", retrucou o Jonathan. "Quem são aqueles ali?", perguntou, apontando para a Lanny e o Frank.

- "Lanny e Frank", respondi com segurança. Conhecia todas as crianças.

O Jonathan olhou em torno, tentando achar alguém mais difícil e me perguntou os nomes de mais três. Respondi a todas as perguntas. Então, com um sorriso malicioso, perguntou: "Ta bom, como se chama minha irmãzinha?". Dessa vez, o Jonathan achou que me pegara. Mas eu sabia o nome da sua irmã. A secretária da escola havia me dado uma lista com os nomes das crianças, de seus pais e de seus irmãos e irmãs. Havia decorado muitas dessas informaçóes e, felizmente para mim, lembrava o nome da irmã do Jonathan.

- "Alicia!", afirmei. Isso me fez me sentir bem. Jonathan ficou muito impressionado. Olhou para a Sue e disse: "Não sei qual é a desse cara", e correu para contar tudo ao Peter e ao Daniel. Enquanto isso, a Sue me deu uma pá.

- "Quer cavar?".

- "Quero", disse, pegando a pá.

Pusemos areia nos baldes e logo o Jonathan, o Peter e o Daniel se juntaram a nós. O Peter e o Daniel perguntaram-me se sabia seus nomes. Obviamente sabia, e disse a eles. Todos começamos a usar nossas pás e as crianças organizaram outro projeto de construção, confiando-me um papel de trabalhador. O Christopher e a Antoinette também se juntaram a nós e a brincadeira continuou por uns 20 minutos, até uma das professoras gritar: "hora de arrumar tudo", e, a contragosto, guardamos nossas pás e fomos para dentro.

Nos dias após essa façanha, as crianças começaram a reagir à minha presença (perguntar quem eu era) e a me convidar para brincar com elas. Embora me deixassem observar e, em muitos casos, participar até um certo ponto das suas brincadeiras, minha aceitação foi gradual. No primeiro mês, as crianças eram curiosas a meu respeito e queriam saber por que eu estava lá todos os dias. Faziam muitas perguntas que seguiam uma seqüência geral: "Quem é você?”; "Cê é professor?"; "Cê vai jogar 
um jogo com a gente?" [isto é, pedir para que participem de experimentos de pesquisa, o que ocorria rotineiramente naquela escola-laboratório]; "Cê é um pai?"; "Cê têm irmãos?". O padrão é importante aqui, pois as crianças passavam de questôes gerais sobre características adultas para a última pergunta a respeito dos irmãos, isto é, uma pergunta que elas costumar fazer umas às outras.

$\mathrm{Na}$ época desse primeiro estudo, minhas respostas a todas as perguntas de informações adultas eram "não", porque eu não era professor, nem pesquisador, nem pai. Em compensação, tenho irmãos - sete! Ter tantos irmãos e irmãs aguçava a curiosidade das crianças a meu respeito. Contudo, algumas hesitavam em acreditar em mim e perguntavam: "De verdade?” Então, para seu deleite, falava o nome de todos. Ter uma família grande ajudou-me a consolidar minha aceitação e entrar no grupo.

Não estou dizendo que as crianças me aceitaram rapidamente como uma delas. Nos meus muitos anos de pré-escolas nunca fui visto completamente como uma das crianças. Até na Itália, onde era visto como um adulto incompetente por causa de meus parcos conhecimentos de italiano (ver abaixo), continuava sendo um adulto. Sou grande demais para ser uma criança, daí o apelido que surgiu quase no fim do primeiro mês, em Berkeley, na cena que descrevi acima. Fui aceito como um adulto diferente ou atípico - uma espécie de criança grande.

Esse status de adulto atípico ou criança grande foi demonstrado de várias maneiras em meu primeiro projeto. Primeiro, permitiam-me entrar no meio de suas atividades de pares com pouca ou nenhuma disrupção. Podia ficar nas casas de boneca, na caixa de areia e até escalar as barras sem muito comentário além de alguns sorrisos e algumas risadas. Segundo, comparado com os outros adultos, eu tinha pouca ou nenhuma autoridade. Em razão do meu desejo de fazer parte da cultura das crianças, não tentava controlar seus comportamentos. Mesmo assim, nas poucas oportunidades em que temi pela sua segurança física, meus avisos de "tome cuidado" eram sempre rebatidos com "Cê não é professor!" ou "Não pode nos dizer o que fazer!". Finalmente, ao longo do ano letivo, as crianças me pediram para participar de atividades de pares mais formais. Nas festas de aniversário, por exemplo, elas insistiam para que eu sentasse com elas (no círculo) e não ficasse em torno como os professores e os pais. Várias crianças também pediam para suas mães escreverem meu nome, junto com os de seus colegas nos biscoitinhos, docinhos e em cartas de dia dos amigos que levavam à escola nos dias especiais. 
Entrada no campo, aceitação e natureza da participação nos estudos...

Bolonha, Itália (1983-1986)

Estava bem preocupado com minha entrada em campo na primeira pré-escola italiana, pois mal compreendia italiano, naquela época, mas isso acabou não durando muito. Com a ajuda de colegas italianos consegui entrar numa pré-escola (scuola dell'infanzia) e apresentar minhas metas de pesquisa (de modo geral, como é ser uma criança na escola) aos professores. $\mathrm{Na}$ Itália, as pré-escolas são federais e mais de $96 \%$ dos italianos entre 3 e 5 anos freqüentam-nas antes de entrar na primeira série, com 6 anos. A escola da qual me tornei parte tinha 5 professores e 35 crianças, entre 3 e 5 anos, misturadas em um só grupo.

No meu primeiro dia na pré-escola os professores apresentaramme às crianças como alguém dos Estados Unidos que vinha à escola para ficar com elas o ano todo. Confiante na estratégia "reativa" de entrada em campo que usara em Berkeley, fui até a área de jogo, sentei e esperei que as crianças reagissem à minha presença. Não demorou muito. Elas começaram a me fazer perguntas e a me chamar para as suas brincadeiras, e com o tempo definiram-me como um adulto atípico.

Para minha surpresa, minha aceitação pelas crianças italianas foi muito mais fácil e rápida que pelas crianças americanas. Para as crianças italianas, assim que começava a falar meu limitado italiano, tornava-me esquisito, engraçado e fascinante. Era não apenas um adulto atípico, mas também um adulto incompetente - não apenas uma criança grande, mas uma espécie de criança grande simplória.

A primeira coisa que notaram foi meu sotaque, mas acostumaramse rapidamente com ele e então perceberam que eu usava muitas palavras erradas (gramática errada) e que o que eu dizia raramente fazia sentido (semântica errada). Primeiro, adoravam rir e corrigir minha pronúncia. Contudo, logo se tornaram pequenos professores, que não apenas corrigiam meu sotaque e minha gramática, mas repetiam e até reformulavam suas próprias falas quando eu não conseguia entender. Às vezes, até representavam palavras. Costumavam juntar-se em pequenos grupos chamando os outros e rindo: "Adivinha o que o Bill acabou de dizer!" Em pouco tempo, estávamos indo muito bem e minha confiança em me comunicar com as crianças começou a crescer. Lembro-me particularmente bem de um dos meus pequenos triunfos.

Estava sentado no chão com dois meninos (Felice e Roberto), brincando de corrida de carrinhos em círculos. O Felice estava falando 
de um corredor italiano enquanto brincávamos, mas ele estava falando tão rápido que apenas conseguia entender parte do que dizia. Contudo, num dado momento, ouvi claramente a frase "Lui è morto", e sabia que significava "Ele morreu". Imaginei que o Felice devia estar contando um acidente trágico nalguma corrida de Fórmula 1. Naquele momento lembrei e usei uma frase particular que aprendera nas minhas primeiras aulas de italiano: "Che peccato?" ("Que pena!").

Olharam para mim maravilhados, e o Felice disse: "Bill! Bill! $H a$ ragione! Bravo, Bill!? (“Bill! Bill! Ele tá certo! Parabéns, Bill!).

- "Bravo, Billl", repetiu o Roberto.

Então o Felice chamou outras crianças na escola. Várias vieram e o escutaram atentamente narrar toda a história do trágico acidente e então acrescentar: "Aí o Bill disse: 'Che peccato!'”. O pequeno grupo aclamoume e alguns até bateram palmas com a notícia. Nada constrangido por tanta atenção, senti-me bem - como um do grupo! Não era mais um adulto tentando aprender a cultura das crianças. Estava dentro dela. Estava conseguindo. Participava!

Entretanto, com as professoras, as coisas não estavam indo tão bem. De fato, as confusões e falhas de comunicaçóes eram freqüentes nos meus primeiros meses na escola. Havia várias razōes para tanto. Primeiro, as professoras e eu éramos autoconscientes dos nossos problemas de língua, ao passo que me sentia à vontade com as crianças. As professoras porque conheciam apenas uma língua, e eu porque meu italiano era tão parco. Segundo, tentávamos falar de assuntos relativamente abstratos (como a política de educação da infância nos Estados Unidos) em contraste com as conversas mais triviais que eu tinha com as crianças quando brincávamos. Terceiro, as professoras não eram tão boas quanto as crianças para reformular suas falas. Embora começassem falando devagar e evitassem construçōes difíceis e expressōes idiomáticas, à medida que a conversa avançava, aceleravam, frases complexas surgiam, e eu ficava perdido. Quando exprimia essa confusão, elas se sentiam um tanto desnorteadas e insistiam para que recomeçássemos. Assim, raramente conseguíamos ir muito longe nessas primeiras tentativas.

Em razão de nossas dificuldades, as professoras surpreendiam-se com meu aparente sucesso comunicativo com as crianças. Várias vezes, eu vi uma ou outra professora chamar as crianças para perguntar do que havíamos falado. As crianças não tinham problemas para repetir aos pro- 
Entrada no campo, aceitação e natureza da participação nos estudos...

fessores o que cada qual havia dito. Essas explicações levaram as professoras a me perguntar por que conseguia comunicar-me tão bem com as crianças. Disse que elas e eu falávamos de coisas mais simples e diretas relacionadas às suas brincadeiras. Embora um pouco perplexos, aceitaram essa explicação e, com o tempo, meu italiano melhorou e também consegui me comunicar com elas.

Uma coisa importante, contudo, foi que a descoberta, pelas crianças, dos meus problemas comunicativos com os professores tornou-se um aspecto especial da nossa relação. Elas podiam falar comigo e eu com elas com pouca dificuldade, mas era claro para elas que este não era o caso com as professoras. De fato, vários pais me contaram que seus filhos ou filhas chegaram em casa dizendo: "Tem aquele americano, Bill, na escola e a gente consegue falar com ele, e as professoras não!" Ou seja, as crianças viam minha relação com elas como uma falha parcial do controle das professoras.

A natureza de minha relação especial com as crianças surgiu claramente num projeto da escola. No começo do ano letivo todas as crianças da escola haviam desenhado pequenos auto-retratos em folhas de papel. Esses retratos individuais foram então compostos numa imagem de grupo muito maior intitulada: "Insieme delle facce dei bimbi della Due Torre" ("todos os rostos das crianças de Due Torre juntos"), que afixaram na parede do salão principal da escola. Due Torre era o nome da escola e essa imagem de conjunto refletia o caráter comunitário do currículo da escola.

Depois as professoras haviam pedido que as crianças falassem um pouco de si. Na época, gravaram suas respostas, transcreveram-nas e colocaram-nas em um portfólio, que deram, no fim do semestre, a cada criança com o retrato da turma e outros materiais produzidos no decorrer do ano. Ao se descreverem, as crianças, em sua maioria, referiam-se a características físicas, diziam se tinham irmãos ou irmãs, bichinhos de estimação, o que gostavam de fazer, e assim por diante. Contudo, uma garota, a Carla, apenas respondeu: "Avevo una borsa" ("Eu tinha uma bolsa"). Apesar da insistência das professoras e de seus colegas, ela não disse mais nada, e presumi que a bolsa perdida era terrivelmente importante para ela, naquela época.

Depois de as crianças acabarem seus auto-retratos, as mais velhas desenharam retratos dos adultos. Este grupo incluiu as professoras, as 
dade (mulheres que trabalhavam na escola, servindo comida e fazendo a limpeza, mas também podiam fazer às vezes de avós substitutas para as crianças), as professoras e eu. Essas imagens também foram compostas num retrato de grupo maior e afixado ao lado do retrato de grupo das crianças com o título: "Insieme degli adulti della Due Torre" "Os adultos de Due Torre juntos"). Fui um dos adultos retratados na imagem.

Depois de todas as crianças terem falado de si mesmas, tiveram a oportunidade, numa reunião do grupo, de fazer comentários sobre os adultos e descrevê-los. Elas descreviam as características físicas das professoras e dades e também fizeram alguns comentários sobre sua personalidade. Disseram que as professoras eram legais, mas também um pouco severas e levantavam a voz quando as crianças se comportavam mal. Mas o ponto principal desta narrativa sobre desenhos e descriçōes foi o que as crianças disseram a meu respeito: Bill è um nomo alto e giovane. Ha $i$ capelli neri, gli occhi marroni e porta gli occhiali, ha la barba. Viene sempre a scuola e gioca con i bimbi, è buono. Bill è Americano e não italiano, si capisce dalla lingua. Con i bimbi parla em italiano: è bravo. ("Bill é um homem jovem e alto. Tem cabelos negros, olhos marrons, usa óculos e tem barba. Sempre vem à escola e brinca com as crianças, ele é bonzinho. Bill é americano, não é italiano, entende a língua. Com as crianças, fala italiano muito bem.").

Essa descrição das crianças demonstra muito bem suas percepções e sentimentos por mim. A seus olhos, era um homem jovem e alto (embora, na realidade, minha altura está um pouco abaixo da média dos homens americanos) e era bonzinho porque sempre ia à escola para brincar com elas. Desse modo, era visto como um amigo. Além do mais, essa relação era especial porque, embora eu seja americano e não italiano, entendia a língua e, com elas, falava a língua muito bem.

Apesar dessas palavras gentis a respeito da minha habilidade com a língua, as crianças nunca cansaram de zombar de meus erros quando falava ou de meus fracassos em entender algo que alguém havia dito. Os menores gostavam muito de zombar de mim. Coisa curiosa, as crianças estendiam minha incompetência com a língua a outras áreas de conhecimentos sociais e culturais.

Uma vez fomos até um zoológico e parque temático com reproduçóes de dinossauros. Durante nossa visita, disse a um pequeno grupo de crianças (em muito bom italiano, por sinal) que o dinossauro que estáva- 
Entrada no campo, aceitação e natureza da participação nos estudos...

mos vendo vivia no mesmo lugar que eu, nos Estados Unidos. De fato, sabia que era verdade porque estava escrito no cartaz ao lado. As crianças soltaram gargalhadas com meu comentário. Um garoto, o Romano, gritou: "O Bill é louco! Diz que esse dinossauro vivia nos Estados Unidos". Então apontando para o dinossauro, acrescentou: "Dá pra ver que vivia aqui mesmo!" Diante da lógica desta rebatida, nem tentei contestar a crítica contra minha afirmação.

\section{Indianápolis, Head Start (1989-1990)}

Indianápolis é minha cidade natal e quando fui conhecer a diretora do Head Start Center e as professoras com quem eu iria trabalhar, descobrimos que tínhamos muitas experiências em comum por termos crescido na cidade. Embora tenham me aceitado rapidamente, quando contei meus planos de visitar o centro duas vezes por semana no ano letivo para aprender a respeito da interação e cultura de pares das crianças, uma professora duvidou. "Por que faria isso?", perguntou. Ela tinha certeza de que logo ficaria aborrecido ou acharia tudo o que precisava saber. Mas, depois de eu cumprir minha palavra durante três semanas, as professoras começaram a aguardar minhas visitas ansiosamente e estabelecemos uma boa relação.

As coisas também foram bem com as crianças, que rapidamente me incluíram em suas brincadeiras. Contudo, de algum modo, minhas primeiras experiências no Head Start Center foram completamente novas para mim. A diferença com o estudo em Head Start é que eu era um homem branco num mundo de mulheres e crianças principalmente negras. Pela primeira vez na minha vida estava passando um tempo considerável num ambiente em que eu era minoria, pois todas as professoras e funcionárias do centro, menos uma, e a esmagadora maioria das crianças eram afro-americanas. Embora eu tivesse uma forte consciência desse fato, ele não parecia preocupar as crianças. Após duas ou três semanas, várias crianças me perguntaram se era o pai de Brandon (um garoto latino-americano). Disse que não e que estava na escola para ficar e brincar com elas. Apenas após aproximadamente dois meses de estudo, uma garota, a Tamera, veio me dizer: "Bill, você é branco!" Sem saber muito bem o que responder, disse: "É, sou". E foi só.

$\mathrm{Na}$ terceira semana na escola, algo importante ocorreu a respeito da minha aceitação e da minha condição de participante na escola, tanto 
para as crianças como para as professoras. O Head Start Center ocupava os prédios de uma antiga escola primária e, ao contrário da maioria das pré-escolas, não havia banheiros para as crianças nas salas de aula. As crianças de pré-escola precisam ir freqüentemente ao banheiro e são pequenas demais para serem autorizadas a irem sozinhas aos banheiros fora das salas de aula.

Portanto, uma das professoras havia de levar as crianças em grupo até um banheiro localizado no meio da escola, duas vezes por turno. Eu acompanhava essas idas e voltas e via a professora formar filas de crianças junto à parede de fora dos banheiros. Mandava então três ou quatro garotos entrarem no banheiro dos meninos e o mesmo número de garotas no das meninas. Ela esperava alguns minutos, entrava em cada banheiro, apressava as crianças e mandava outra leva até todas as crianças terem tido sua vez. Então, retornávamos todos para a sala de aula com a professora lembrando às crianças que deviam ficar em fila, andar devagar e ficarem quietas para não atrapalhar as outras aulas.

Embora esta não fosse uma tarefa particularmente agradável para as professoras, fiquei surpreso quando, uma manhã, uma delas pediume para levar as crianças ao banheiro. Esse pedido parecia perfeitamente razoável. Afinal não era uma tarefa complicada. Além do mais, como ia junto com elas, por que não levá-las sozinho?

O problema é que não queria que as crianças me vissem como uma figura de autoridade, e havia comentado esse aspecto de minha pesquisa com as professoras. Entretanto, era claro que elas não pensavam que essa pequena tarefa me causaria problemas, ou simplesmente não lembraram disso quando pediram esse favor. Decidi concordar e ajudar, e esperei que isso não atrapalhasse muito minha relação de adulto atípico com as crianças. No fim das contas, acabei ganhando muito mais do que podia esperar, pelo menos na nossa primeira ida ao banheiro.

As coisas começaram bem. Percebi alguns sorrisos no rosto das crianças quando a professora disse que eu ia levá-las. Quando estávamos saindo da sala, ela lhes pediu para se comportarem bem. No corredor e na descida da escada, pareciam anjinhos: não falavam nem corriam, até a fila estava perfeitamente reta. Também foram ordenadas ao formarem a fila na porta dos banheiros (os meninos diante do dos meninos, e as meninas diante do das meninas).

Mandei entrar os quatro primeiros meninos da fila (Charles, Luke, Joseph e Antwaan) assim como as quatro primeiras meninas (Cymira, 
Entrada no campo, aceitação e natureza da participação nos estudos...

Tasha, Michelle e Lamecca ) no seu respectivo banheiro. Depois de alguns minutos, ouvi muito barulho no banheiro dos meninos.

- “O que estão fazendo?", indagou o Jeremiah. Era justamente o que estava me perguntando. Quando fui ver, logo vi que estava com problemas. O Joseph havia feito bolas com toalhas de papel e as jogava nos três outros. O Antwaan estava na pia e, com a mão debaixo da torneira aberta ao máximo, esguichava água por todo canto. Enquanto isso Charles e Luke estavam soltando gargalhadas, pois tentavam urinar cada um no mictório do outro.

- "Oh, rapazes", disse; "Parem com isso e já para fora".

- "Não pode nos dizer o que fazer", disse o Charles, que pelo menos voltou à posição normal e urinava no seu próprio mictório.

- "É, ele tá certo", acrescentou o Antwaan; "Cê não é professor".

Então ouvi muito barulho lá fora e fui correndo ver. Todas as crianças queriam ter sua vez e perguntavam quando iam poder entrar. $\mathrm{O}$ Brandon, o mais insistente, gemia: "Preciso fazer xixi!" Eu também precisava, mas, no momento, era o que menos me preocupava. Entrei de novo no banheiro e percebi que tentar ser duro não ia ajudar muito. Agora, o Charles e o Luke estavam imitando o Joseph e jogavam bolas de toalha de papel, uma das quais me atingiu atrás da cabeça enquanto impedia o Antwaan de jogar mais água, fechando a torneira.

Antes de os meninos poderem me afrontar, disse: "Não sou professor, mas a turma da Sra. Green vai chegar logo. Se vocês não saírem, vamos todos ter problemas".

- "É, o Bill tá certo", disse Charles; "Melhor sair".

Os outros concordaram e fiz os de fora entrarem rapidamente, inclusive o Brandon, que correu o mais rápido que pôde. Graças a Deus, não molhou as calças. Foi então que percebi que as quatro primeiras meninas ainda não tinham saído, e que havia muito barulho no banheiro delas. Enfiei a cabeça para ver, mas Tasha gritou: "Meninos não podem entrar!" As professoras não tinham esse problema, pois entravam no banheiro dos meninos para apressá-los sem problemas. Decidi respeitar o aviso da Tasha, mas já estava preparado. voz alta.

- "Parece que a turma da Sra. Green está chegando", disse em 
- "Xiiii", ouvi a Michelle exclamar.

- "É, vamos", disse a Cymira. As quatro saíram logo e as outras meninas entraram.

As segundas levas de crianças também brincaram um pouco, mas respeitaram minha advertência quanto à turma da Sra. Green. Logo, todas as crianças haviam acabado e formado a fila para podermos ir. Várias estavam sorrindo, e o Charles comentou: "É engraçado ir ao banheiro com o Bill!". Voltamos então à sala de aula com as crianças se comportando tão bem como na ida. De volta à sala, a Sra. Jones disse:

- "Demoraram, espero que não tenham dado trabalho ao Bill".

- "Não, senhora", respondeu o Charles, olhando para mim com um sorriso.

- "Gostamos de ir com o Bill", acrescentou a Tasha.

Sentia-me fora de perigo. Havia jogado fora todas as toalhas de papel e, se o chão do banheiro dos meninos ainda estava bem molhado, provavelmente secaria até a turma da Sra. Green chegar lá.

Alguns dias depois, as turmas da tarde ficaram sabendo que levara as crianças ao banheiro de manhã, e pediram-me para levar as da tarde também. Elas me deram trabalho na primeira vez, mas já estava preparado. $\mathrm{Na}$ verdade, esse papel me aproximava mais das crianças, pois, embora soubessem que podiam brincar um pouco nos banheiros e me dar um pouco de trabalho, percebiam que havia um limite para suas brincadeiras. Como no caso das crianças italianas, compartilhamos algumas experiências fora do controle das professoras. Com isso, meu status de adulto especial e engraçado consolidou-se.

\section{Modena, Itália (1996-2001)}

Em Modena, na Itália, com minha colega italiana Luisa Molinari, fiz um estudo sobre a transição das crianças da pré-escola à escola primária. Nós continuamos nosso estudo por meio de observações e entrevistas nos seguintes cinco anos das crianças da escola primária; seu enfoque principal era os cinco últimos meses de pré-escola e os quatro primeiros meses de primeira série das crianças.

Meus primeiros dias na pré-escola de Modena representaram um novo desafio para mim. Pela primeira vez, encontrava-me numa pré-es- 
Entrada no campo, aceitação e natureza da participação nos estudos...

cola em que eu era o único verdadeiro principiante. Nas pesquisas anteriores, entrava nas escolas no começo do semestre e pelo menos algumas das crianças (quando não todas) estavam, como eu, num ambiente novo. Além disso, neste exemplo, não apenas eu entrava no grupo no meio do ano letivo, mas quase todas as crianças e as professoras já se conheciam havia dois anos e meio. Isso, junto com o fato de eu ser estrangeiro, aguçou muito a curiosidade de adultos e crianças a meu respeito durante meus primeiros dias na escola.

Como havia feito nas pesquisas anteriores, cheguei às áreas dos brinquedos, sentei e deixei as crianças reagirem à minha presença. Algumas das mais velhas e mais ativas de uma turma (Luciano, Elisa e Marina) me contavam o que estava acontecendo e cuidaram de mim durante as primeiras semanas. Acompanhavam-me até as aulas de música e de inglês, e ouvi que se referiam a mim, com as crianças das outras turmas de 4 e 5 anos da escola, dizendo: "O Bill é da nossa turma!"

Embora as crianças gostassem da idéia de me ter em sua turma, como havia ocorrido em Bolonha, elas zombavam da minha pronúncia errada e dos meus erros de gramática, e afirmavam que "hanno capito niente" ("não entendiam nada") do que estava dizendo. Várias crianças davam tapinhas no meu estômago, rindo de minha "pancia grande" ("barrigão"). Um dia, quando já estava na escola havia três semanas, estava sentado numa área onde uma menina, a Carlotta, que costumava zombar de mim, estava brincando de bonecas com várias outras meninas. De repente, ela levantou o meu suéter, pôs sua boneca por baixo e chamou todas: "Olhem, o Bill tá grávido!" Então tirou a boneca em meio às gargalhadas.

As crianças também não hesitavam em recusar algumas de minhas idéias ou reivindicações. Uma vez, brincando no pátio de fora com várias crianças, percebi que o Dario, o Renato e o Valerio estavam juntando umas varetas de madeira no chão, debaixo das barras de escalada, para protegê-las dos outros, e discutiam a respeito de fogo. Disse, então, que os índios acendiam o fogo esfregando dois paus juntos. O Renato e o Valerio decidiram tentar, mas o Dario disse (com todas as letras): "O Bill é 'pazzo' ('louco'), não sabe do que tá falando, não vai funcionar”. Os outros concordaram rapidamente e decidiram usar as varinhas para remexer as folhas.

Em contrapartida, as crianças percebiam que, na qualidade de adulto, eu tinha certas habilidades que lhes podiam ser úteis. Uma vez o 
Renato, o Angelo, o Mario e o Dario estavam brincando com blocos de construção de plástico de encaixar. Deram-me alguns que estavam encaixados e pediram se podia separá-los. Aceitei essa tarefa de bom grado, mas logo percebi que as peças estavam muito mais bem grudadas do que julgara. De fato, comecei a puxar com toda a força sem sucesso. A Giovanna, uma das professoras, passou por perto, riu e disse que as crianças haviam encontrado um uso prático para mim. Percebi que muitas peças estavam provavelmente presas juntas há muito tempo. Já estava pensando em abandonar a tarefa, quando tentei segurar uma peça na borda da mesa e a outra no ar. Puxei com força e as duas peças se soltaram. O Angelo e o Renato gritaram: "Parabéns, Bill!", e imediatamente me deram várias outras peças. Separei facilmente as duas primeiras com meu método inventivo, mas tive mais problemas, pois várias peças simplesmente não se soltavam. Entretanto, os meninos estavam imitando o meu método com um certo sucesso, então insisti. Notei então que o Angelo e o Mario estavam guardando todas as peças separadas de volta na caixa. Contaram a várias outras crianças que o Bill conseguira separá-las, mas que não iam brincar com elas. Perguntei-me o porquê disso. Será que estavam com medo de as peças grudarem de novo? Seja como for, continuei trabalhando na minha tarefa ingrata até ouvir, para o meu alívio, Giovanna dizer que estava na hora de guardar tudo.

Uma manhã, depois de eu ter observado a escola por umas cinco semanas, Giovanna estava lendo um capítulo de $O$ Mágico de $\mathrm{Oz}$ para as crianças. Após mais ou menos dez minutos de leitura e discussão, chamaram-na para atender um telefonema e ela me deu o livro, sugerindo que continuasse lendo a história. Conscientes de que seria uma tarefa difícil para mim, as crianças gritaram e bateram palmas pensando que era uma ótima idéia. Logo tive problemas para pronunciar a palavra "espantalho", em italiano: "spaventapasseri". As crianças riam e gritavam com minhas trombadas nesta e em outras palavras. Algumas crianças até se jogaram no chão fingindo crises de histeria diante da minha situação. Minha tarefa era mesmo muito complicada, pois parecia haver um "espantalho” em cada frase. Para meu alívio, a Giovanna voltou e, quando perguntou como tinha me saído, as crianças riram e disseram que eu não sabia ler muito bem. A Sandra gritou: "Não entendemos nada!" A Giovanna então pegou o livro de volta, mas as crianças gritaram: "Não, queremos que o Bill leia mais!” Pegando o livro de volta, penei para ler mais uma página em meio às risadas animadas das crianças antes de devolver o livro a Giovanna dizendo: "Basta cosi, adesso" ("Agora chega"). 
Entrada no campo, aceitação e natureza da participação nos estudos...

Aqui, dois aspectos da resposta das crianças a meus problemas com a língua diferem dos das minhas experiências anteriores, em Bolonha. Primeiro, em Bolonha, observava um grande grupo de crianças com idades misturadas e competências de leitura e escrita muito diversas. Além do mais, embora as crianças de Bolonha fossem iniciadas à leitura e à escrita, isso não era uma parte central do currículo. No grupo de crianças de 5 anos de Modena, havia aulas e atividades relacionadas à leitura e escrita todos os dias, naquele segundo semestre de seu último ano na préescola. Embora rissem dos meus erros, percebiam que eu sabia ler, e identificavam-se com meus problemas até um certo ponto. Segundo, as crianças de Modena também estudavam inglês e percebiam que eu era competente naquela língua estrangeira que era muito difícil para elas. $\mathrm{Ou}$ seja, era tranqüilizador, para elas, que esse novo adulto no meio delas compartilhasse alguns de seus desafios e experiências.

Em julho, quase no fim do ano na pré-escola de Modena, havia me tornado um bom amigo das crianças, das professoras e de muitos pais. Estava muito feliz de poder ir à escola primária junto com as crianças, no outono. Das 21 crianças que acompanhara, 18 (3 foram para outra escola primária) foram divididas em 4 turmas, na primeira série. Observava um dos 4 grupos a cada dia e passava a maioria de minhas sextasfeiras com as professoras da pré-escola e suas novas turmas de crianças de 3 anos. No começo, na escola primária, as crianças de nossa antiga préescola tentaram me reivindicar, dizendo: "O Bill, é nosso!" Contudo, depois de algumas semanas passei a conhecer todas as outras crianças e quando fui embora, em dezembro, crianças e professoras viam-me como parte da primeira série! Continuei sendo membro deste grupo com suas professoras durante toda a escola primária.

Entretanto, ocorreu um incidente no começo do meu tempo de primeira série que me deixou uma lembrança particular e demonstra minha amizade profunda com as crianças da primeira pré-escola. Foi em meados de outubro de 1996, e já estava com as crianças da primeira série por pouco mais de um mês. Estava observando a Prima $B$ (primeira série, grupo B) e a professora, Letizia, estava movendo as mesas, pois as crianças da Prima $A$ iriam participar da aula. Enquanto eu a ajudava, senti o chão começar a mexer. Era um terremoto.

- "Temos de levar as crianças para fora", disse a Letizia, enquanto saía rapidamente da sala. 
Assumi que eu havia de tomar conta das várias crianças na sala enquanto ela ia buscar as que estavam no corredor, no banheiro ou ainda estavam na sala da Prima $A$. Tudo isso foi muito rápido, e não apenas o chão tremeu por vários segundos, mas parecia que estava cedendo, dando-me a impressão de que estava andando num colchão de água. Juntei as cinco crianças da sala e fomos para fora, onde vi grupos de professoras e alunos se juntarem perto do portão principal. Estavam agrupados por turmas. Algumas das crianças mais velhas estavam apavoradas e choravam, mas o tremor já havia parado. Olhando os prédios mais altos em torno da escola, podia ver que não havia estragos visíveis.

Enquanto levava minhas crianças para se juntar ao resto da Prima $B$, percebi que, para se protegerem da forte garoa, várias crianças se dirigiam a uma pequena área fechada, onde guardavam bicicletas. Os professores logo as mandaram sair dali - tratava-se de ficar longe de qualquer coisa que pudesse desmoronar - e voltarem para seu grupo. Então, um garoto da Prima $A$, o Mario, que também já conhecia da pré-escola, saiu correndo rumo à escola. Fui atrás dele, mas uma das professoras foi mais rápida que eu e o levou de volta a seu grupo.

- "Mas preciso do meu lápis favorito", protestou ele.

- "Está louco", disse a professora; "Estamos em pleno terremoto, você pega o lápis depois".

Várias crianças da pré-escola que estavam na Prima $B$ já tinham se aproximado de mim e seguravam meus braços ou minhas pernas enquanto a professora explicava que um terremoto estava ocorrendo. Depois de mais alguns minutos as coisas se acalmaram e as professoras deixaram as crianças circularem entre as turmas. Várias crianças da Prima $A, C$ e $D$, que estavam na pré-escola comigo, vieram correndo me perguntar: "Bill, você também teve um terremoto na sua classe?".

Acabei ficando com essas crianças até o fim de seu tempo no primário, voltando todas as primaveras (menos uma) para fazer observaçóes e entrevistas, e trocando cartas com elas. Com o tempo, tornei-me um membro ativo desse grupo de crianças, parte da primeira série, depois, da segunda, e assim por diante. À medida que os aspectos de sua cultura de pares se desenvolviam e mudavam, eu era aceito em novas rotinas, atividades e conversas de uma cultura de pares que era mais refletivamente compartilhada e avaliada. Isto é, as crianças falavam entre si e comigo de suas amizades, atividades, visões dos trabalhos escolares e das professoras, 
Entrada no campo, aceitação e natureza da participação nos estudos...

e de suas famílias. Enquanto teria sido muito mais difícil entrar como adulto, digamos, numa quarta ou quinta série, e participar dessas conversas e avaliações, não tive problemas, pois a minha presença e meu interesse pelas suas vidas eram vistos como naturais. Então pude perguntar às crianças e escutá-las falarem a respeito de suas mudanças de amizades, seu crescente interesse pelo sexo oposto, suas percepções da transição para a escola secundária e seus sentimentos ao deixarem a escola primária e das professoras que haviam ocupado uma parte importante de suas vidas. Esta é uma vantagem única da etnografia longitudinal, pois o pesquisador cresce com as crianças e compartilha diretamente suas vidas como um amigo adulto especial.

Recebido em novembro de 2004 e aprovado em março de 2005.

Referências bibliográficas

ADLER, P.; ADLER, P. Peer power. New Brunswick: Rutgers University Press, 1998.

CHRISTENSEN, P.; JAMES, A. (Ed.). Research with children: perspectives and practices. London: Falmer Press, 2000.

CORSARO, W.A. Friendship and peer culture in the early years. Norwood: Ablex, 1985.

CORSARO, W.A.; MOLINARI, L. Entering and Observing in Children's Worlds: a reflection on a longitudinal ethnography of early education in Italy. In: Christensen, P.; James, A. Research with children: perspectives and practices. London: Falmer Press, 2000.

FINE, G.; SANDSTORM; K. Knowing children: participant observation with minors. Newbury Park: Sage, 1988.

MANDELL, N. The least-adult role in studying children. Journal of Contemporary Ethnography, n. 16, p. 433-467, 1988.

RIZZO, T.; CORSARO, W.A.; BATES, A. Ethnographic methods and interpretative analysis: expanding the methodological options of psychologists. Developmental Review, n. 12, p. 101-123, 1992. 